\title{
MODEL ESTIMATION OF THE WHOLE LIFE COST OF A BUILDING WITH RESPECT TO RISK FACTORS
}

\author{
Damian WIECZOREK, Edyta PLEBANKIEWICZ*, Krzysztof ZIMA \\ Institute of Construction Management, Tadeusz Kościuszko Cracow University of Technology, \\ Warszawska 24 St., 31-155 Kraków, Poland
}

Received 27 March 2018; accepted 14 October 2018

\begin{abstract}
The paper deals with estimating the life cycle cost and the whole life cost of a building. An original model for estimating the life cycle cost and the whole life cost of a building which allows the quantification of the increase in costs resulting from the incurred and assessed risk is presented. The proposed model consists of two basic parts: module I evaluating the impact of identified risk factors on individual element of the life cycle cost, and module II allowing to assess life cycle cost including the risk factors selected in module I. In module I the model of fuzzy inference of Mamdani was used. The structure of module II is based on the theory of possibilities and fuzzy sets. The operation of the model is presented on the example of an office building.
\end{abstract}

Keywords: risk, life cycle, life cycle cost, cost estimation, fuzzy sets.

JEL Classification: C51, D81.

\section{Introduction}

The idea of life cycle cost $(L C C)$ began in the mid-60s of the twentieth century when the US Department of Defense applied the $L C C$ concept to assess the cost of purchasing and using armaments systems. In the mid-1980s, attempts were made to adapt this concept to construction investment (Gluch \& Baumann, 2004). The person considered to be the precursor of the life cycle costing techniques is Peter Albert Stone whose publication (Stone, 1967) concerned the adaptation of the LCC concept but only to the costs associated with the use and maintenance of the building, namely, to the cost in use. Attempts from the 80s of the twentieth century to adapt the concept of life cycle cost to all types of costs (including initial costs and costs of withdrawal) that may occur in the life cycle of a building investment led to an increase in operating costs, particularly these related to the use of energy during the operation of a building (Sterner, 2002; Kale, Joshi, \& Menon, 2016; Koo, Hong, \& Park, 2018).

${ }^{\star}$ Corresponding author. E-mail: eplebank@L3.pk.edu.pl

This is an Open Access article distributed under the terms of the Creative Commons Attribution License (http://creativecommons. org/licenses/by/4.0/), which permits unrestricted use, distribution, and reproduction in any medium, provided the original author and source are credited. 
Thus life-cycle costing techniques began to develop dynamically (Flanagan \& Norman, 1983; Robinson, 1986; Flanagan, Kendell, Norman, \& Robinson, 1987; Bromilow \& Pawsay, 1987).

In the $90 \mathrm{~s}$ of the previous century and at the beginning of the twenty-first century, research into the possibility of implementing non-deterministic methods into life cycle costing. Life cycle costing models are mostly deterministic ones based on an economic feasibility study, using a discount account to reflect the change in the value of money over time. Such models for various construction objects and also considering the various cost groups have been developed by, among others, Aye, Bamford, Charters, and Robinson (2000); Hasan, Vuolle, and Siren (2008) or Marszal and Heiselberg (2011); Zavadskas, Antuchevičienè, and Kapliński (2015a, 2015b). Goh and Yang (2010) as well as Yi and Wen-jie (2009) or Plebankiewicz, Zima, and Wieczorek (2015) developed models using for example an analytical hierarchical model (AHP).

Life cycle cost have also found their normative approach. ISO 15686-5:2008. "Buildings and constructed assets. Service life planning. Part 5: Life cycle costing” (International Organization for Standardization [ISO], 2008) include the definitions of life cycle and the so-called "whole life cycle". The definitions can be illustrated as in Figure 1.

Life cycle cost constitute an issue which has been around for some time in the sphere of interest of the European Union. In terms of the provisions of the classical directive (2014/24/ UE), Member States may provide that public contracting authorities cannot use the price alone as the sole criterion for the award of the contract. With reference to these provisions and EU requirements, individual countries introduce legislation defining the notion of life cycle cost of the object of the contract that can be used as the so-called cost criterion which is to be an alternative to the popular price criterion. These conditions have resulted in an ever-widening search for methods that accurately determine the costs of the life cycle of a particular building.

The life cycle cost analysis may be performed with use of simple or complex methods. Simple methods are applied only in cases of uncomplicated comparisons. Their basic limitation is to involve calculations but excluding the effect of changes in the time value of money and changes in energy prices. On the other hand, complex methods are based on mathematical economic models which consider changes in the time value of money (discounting).

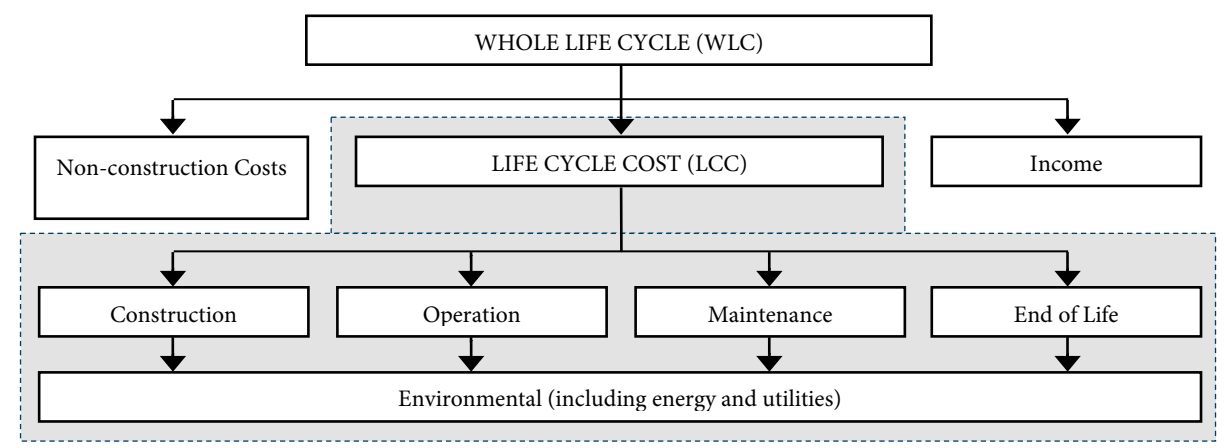

Figure 1. Elements of whole life cycle (WLC) and life cycle cost (LCC) (source: own study based on standard drawing 2, ISO, 2008) 
An example of a complex method is the analysis of the effectiveness of investments in their life cycle ( $L C N P V)$ based on discounted cash flow with consideration of environmental impacts. The basic calculation formula is as follows (Plebankiewicz, 2014):

$$
L C N P V=\sum_{i=0}^{E S L B} \frac{C F_{i}}{(1+r)^{i}},
$$

where: $C F_{i}$ - cash flow in $i$-th year, ESLB - estimated service life in years, $i$ - subsequent year, $r$ - discount rate.

Costs incurred in the life cycle of a building are influenced by a number of factors, ones that are predictable that can be evaluated, as well as ones that are unpredictable. As a result, to estimate the costs one has to consider the different types and degrees of uncertainty and risk. The breakdown of risk factors by category, related entity, and life cycle stages with example factors are presented in Table 1.

Table 1 . Division of risk factors by category and the entity directly related to them for residential buildings and service facilities (source: own study based on Zhi, 1995; N. A. Kartam \& S. A. Kartam, 2001; Wiguna \& Scott, 2006; Shevchenko, Ustinovichius, \& Andruškevičius, 2008; Ilg, Scope, Muench, \& Guenther, 2017; Oduyemi, Okoroh, \& Fajana, 2016; Yuting \& Carmichael, 2018)

\begin{tabular}{|c|c|c|c|c|c|c|c|c|}
\hline \multirow{2}{*}{ Risk category } & \multirow{2}{*}{ Risk factors } & \multicolumn{3}{|c|}{ Entity } & \multicolumn{4}{|c|}{ Life cycle phase } \\
\hline & & In & $\mathrm{D}$ & $\mathrm{C}$ & $\mathrm{P}$ & I & $\mathrm{O}$ & $\mathrm{W}$ \\
\hline \multirow{3}{*}{ Technological } & errors in projects & & $\mathrm{X}$ & & $\mathrm{X}$ & & & \\
\hline & mistakenly recognized ground conditions & & $\mathrm{X}$ & & $\mathrm{X}$ & & & \\
\hline & failure frequency of construction equipment & & & $\mathrm{X}$ & & $\mathrm{X}$ & & \\
\hline \multirow{3}{*}{$\begin{array}{l}\text { Building, } \\
\text { implementa- } \\
\text { tion }\end{array}$} & unfavorable weather conditions & & & $\mathrm{X}$ & & $\mathrm{X}$ & $\mathrm{X}$ & $\mathrm{X}$ \\
\hline & delays in the execution of construction works & & & $\mathrm{X}$ & & $\mathrm{X}$ & $\mathrm{X}$ & $\mathrm{X}$ \\
\hline & use of unsuitable building materials & & $\mathrm{X}$ & $\mathrm{X}$ & & $\mathrm{X}$ & $\mathrm{X}$ & \\
\hline \multirow{3}{*}{ Financial } & $\begin{array}{l}\text { absence (or delay) of payment for the works } \\
\text { performed }\end{array}$ & $\mathrm{X}$ & $\mathrm{X}$ & $\mathrm{X}$ & $\mathrm{X}$ & $\mathrm{X}$ & $\mathrm{X}$ & $\mathrm{X}$ \\
\hline & loss of financial liquidity of the entity & $\mathrm{X}$ & $\mathrm{X}$ & $\mathrm{X}$ & $\mathrm{X}$ & $\mathrm{X}$ & $\mathrm{X}$ & $\mathrm{X}$ \\
\hline & rise in prices of building materials & $\mathrm{X}$ & & $\mathrm{X}$ & & $\mathrm{X}$ & $\mathrm{X}$ & \\
\hline \multirow{3}{*}{ Political } & volatility in tax systems & $\mathrm{X}$ & $\mathrm{X}$ & $\mathrm{X}$ & $\mathrm{X}$ & $\mathrm{X}$ & $\mathrm{X}$ & $\mathrm{X}$ \\
\hline & volatility in the legislative system & $\mathrm{X}$ & $\mathrm{X}$ & $\mathrm{X}$ & $\mathrm{X}$ & $\mathrm{X}$ & $\mathrm{X}$ & $\mathrm{X}$ \\
\hline & instability of economic development & $\mathrm{X}$ & $\mathrm{X}$ & $\mathrm{X}$ & $\mathrm{X}$ & $\mathrm{X}$ & $\mathrm{X}$ & $\mathrm{X}$ \\
\hline \multirow{3}{*}{ Ecological } & $\begin{array}{l}\text { wrong design assumptions on environmental } \\
\text { issues }\end{array}$ & & $\mathrm{X}$ & & $\mathrm{X}$ & $\mathrm{X}$ & $\mathrm{X}$ & $\mathrm{X}$ \\
\hline & lack of legislative system on environmental issues & $\mathrm{X}$ & $\mathrm{X}$ & $\mathrm{X}$ & $\mathrm{X}$ & $\mathrm{X}$ & $\mathrm{X}$ & $\mathrm{X}$ \\
\hline & $\begin{array}{l}\text { variation of state position on environmental } \\
\text { issues }\end{array}$ & $\mathrm{X}$ & $\mathrm{X}$ & $\mathrm{X}$ & $\mathrm{X}$ & $\mathrm{X}$ & $\mathrm{X}$ & $\mathrm{X}$ \\
\hline \multirow{3}{*}{ Legal } & difficulty in obtaining permits & $\mathrm{X}$ & $\mathrm{X}$ & & $\mathrm{X}$ & & $\mathrm{X}$ & $\mathrm{X}$ \\
\hline & incompatibility with legal acts & $\mathrm{X}$ & $\mathrm{X}$ & $\mathrm{X}$ & $\mathrm{X}$ & $\mathrm{X}$ & $\mathrm{X}$ & $\mathrm{X}$ \\
\hline & discrepancies in documentation & & $\mathrm{X}$ & & $\mathrm{X}$ & $\mathrm{X}$ & $\mathrm{X}$ & $\mathrm{X}$ \\
\hline
\end{tabular}

Entity: IN - investor, D - designer, C - contractor;

Life cycle phases: $\mathrm{P}$ - programming phase, I - implementation ph., $\mathrm{O}$ - operation ph., $\mathrm{W}$ - withdrawal ph. 
The number of mathematical models estimating life cycle cost in construction, whose authors focused especially on the possibility of risk factors occurrence in the particular phases of the life cycle, is not that numerous.

These publications include the one of which presents a method of optimizing the life cycle repair strategy of the element in the life cycle of concrete bridge girders which, when corroding during use, can lead to the failure of the structure (Frangopol, Lin, \& Estes, 1997). The authors link all cost types with the probability of the occurrence of failure (the identified risk factor) which may or may not be diagnosed during the planned condition checks. The study of Sobanjo (1999) describes a method based on the fuzzy sets theory which analyses the life cycle cost of buildings. Using this conceptual approach, the author illustrates how risk can influence the cost of the project due to the subjective approach of experts to the estimation of the building life cycle cost. Fuller and Boyles (2000) consider probabilistic techniques that can prove helpful in risk-related procedures that may be accompanied by heat pump-based installation systems. The paper by Menassa (2011) depicts way of determining the value of investment costs related to the modernization of existing buildings with respect to the tenets of sustainable development. The author takes into account the uncertain events taking place in the project which are related to the negative impact of the risk on the value of the cycle. Leśniak and Zima (2018) proposed an approach to estimate the costs of sports field construction using the Case Based Reasoning method. In analysis, they distinguished 16 factors that affect the cost of a construction project with such sustainable factors as environmental impact of the building, ecological materials used and the impact of the facility on the surroundings. Ammar, Zayed, and Mosehli (2012) deal with the evaluation of individual alternatives in terms of the annual cost index for the different operating periods of the surveyed buildings. Additionally, for each cost type, the impact of risk on their value is modelled using the fuzzy sets theory, in particular, the fuzzy net present value (fuzzy NPV).

It is very important that the ISO 15686-5:2008 standard (ISO, 2008) notes in chapter 8 ("Uncertainty and Risks") there is no common methodology for calculating the life cycle cost in the construction industry with consideration of the risk factors in the form of a quantitative risk supplement.

The main aim of this paper is to present the author's proposal of a model for estimating the life cycle cost (and the whole life cost) of a building that takes into account the risk in the form of a quantitative risk supplement which will be one of the possible comparison criteria for the decision maker (investor) in choosing the best solution for the anticipated construction investment. This model can complement the lack of methodology for calculating the life cycle cost in the construction industry with consideration of the risk factors about which the ISO 15686-5:2008 standard (ISO, 2008) mentions.

\section{A schema of the life cycle cost estimation model of a building considering the additive for risk}

The proposed model consists of two basic parts: module I evaluating the impact of identified risk factors on the individual element of life cycle cost, and module II allowing to assess life cycle cost including the risk factors selected in module I. 


\subsection{Module I}

The main goal of the proposed fuzzy approach to the risk assessment is to answer the question: is it necessary to consider the impact of the identified risk factor on a given component of the life cycle cost of a building.

The model of the reasoning mechanism is built on the linguistic description of two distinctive criteria for risk (input variables), that is criterion $X_{1}$ - probability of a unwanted phenomenon - marked as $P R(U p h)$, input variable $x_{1}$ and criterion $X_{2}$ - effect of occurrence of a unwanted phenomenon - marked as $\operatorname{EFF}(U p h)$, input variable $x_{2}$. The model assumptions are described in more details in author's publication (Plebankiewicz \& Wieczorek, 2016).

Uncertainty and imprecision attributed to the data that are necessary in the inference process, takes the form of fuzzy information. Therefore, it was decided to use the theory of fuzzy sets to create the reasoning mechanism. Due to the small number of input variables and thus the minimal possible number of reasoning rules, to the construction of the model, the model of fuzzy inference of Mamdani was used (Mamdani, 1974, 1977). This model consists of three main processes, ie. fuzzification, inference, and defuzzification.

\subsubsection{Fuzzification}

Table 2 and Table 3 presents fuzzy interpretations of linguistic values for input variables $x_{1}$ and $x_{2}$. They defined families of fuzzy sets $L(X)$ and described the fields of input variables on universes $u_{1}$ and $u_{2}$. Membership functions of fuzzy numbers with triangular and trapezoid graphs are interpreted as the four-tuple $\left\{\alpha_{1}, \alpha_{2}, \alpha_{3}, \alpha_{4}\right\}$, which denote the intervals of the values of $1.0\left\{\alpha_{2}, \alpha_{3}\right\}$ or the left or right width of function distribution $\left\{\alpha_{1}, \alpha_{4}\right\}$.

Table 2. Fuzzy interpretation of the linguistic input variable $x_{1}-P R(U p h)$

\begin{tabular}{|l|c|c|c|}
\hline \multicolumn{2}{|c|}{$A_{j}$ fuzzy set of linguistic values for $P R(U p h)$} & $\begin{array}{c}\text { Description } \\
\text { of the variable } x_{1}\end{array}$ & $\begin{array}{c}\text { Fuzzy evaluation } \\
\text { of membership } \mu\left(x_{1}\right)\end{array}$ \\
\hline Very high & Vh & About or above 0.9 & $(0.7,0.9,1.0,1.0)$ \\
\hline Quite high & $\mathrm{Qh}$ & About 0.7 & $(0.5,0.7,0.7,0.9)$ \\
\hline Average & $\mathrm{Av}$ & About 0.5 & $(0.3,0.5,0.5,0.7)$ \\
\hline Quite low & $\mathrm{Ql}$ & About 0.3 & $(0.1,0.3,0.3,0.5)$ \\
\hline Very low & $\mathrm{Vl}$ & About or below 0.1 & $(0.0,0.0,0.1,0.3)$ \\
\hline
\end{tabular}

Table 3. Fuzzy interpretation of the linguistic input variable $x_{2}-E F F(U p h)$

\begin{tabular}{|l|c|c|c|c|}
\hline \multicolumn{2}{|c|}{$\begin{array}{c}B_{j} \text { fuzzy set of linguistic } \\
\text { values for } E F F(U p h)\end{array}$} & $\begin{array}{c}\text { Description } \\
\text { of the variable } x_{2}\end{array}$ & $\begin{array}{c}\text { Fuzzy evaluation } \\
\text { of membership } \mu\left(x_{2}\right)\end{array}$ & $\begin{array}{c}\text { Impact on individual costs } \\
\text { of a life cycle of a building object }\end{array}$ \\
\hline Very important & Vi & About 5 & $(4,5,5,5)$ & $\begin{array}{c}\text { Associated costs: Always } \\
\text { Derivative costs: Always }\end{array}$ \\
\hline Quite important & Qi & About 4 & $(3,4,4,5)$ & $\begin{array}{c}\text { Associated costs: Always } \\
\text { Derivative costs: Sometimes }\end{array}$ \\
\hline Average & Av & About 3 & $(2,3,3,4)$ & $\begin{array}{c}\text { Associated costs: Sometimes } \\
\text { Derivative costs: Rarely }\end{array}$ \\
\hline $\begin{array}{l}\text { Almost } \\
\text { insignificant }\end{array}$ & Ai & About 2 & $(1,2,2,3)$ & $\begin{array}{c}\text { Associated costs: Rarely } \\
\text { Derivative costs: Never }\end{array}$ \\
\hline Insignificant & In & About 1 & $(1,1,1,2)$ & $\begin{array}{c}\text { Associated costs: Never } \\
\text { Derivative costs: Never }\end{array}$ \\
\hline
\end{tabular}




\subsubsection{Inference}

The task of the inferential block is to calculate output variable y - impact of identified risk factor on a given component of the life cycle cost of a building - marked as IRF(Uph), based on input degrees of membership. The output variable is a function that is often complex in shape. Its calculation is done by the inference (also called reasoning process), which must have defined two basic elements ie. base rules and inference mechanism. The developed base rules has a conjunctive form. It consists of 25 rules, which are shown in Table 4 . Table 5 presents fuzzy interpretation of the linguistic output variable $y-\operatorname{IRF}(U p h)$.

Table 4. Rules for the inferential block

\begin{tabular}{|c|c|c|c|c|c|c|c|}
\hline Rule No. & If $\left(x_{1}\right)$ & And $\left(x_{2}\right)$ & Then $(y)$ & Rule No. & If $\left(x_{1}\right)$ & And $\left(x_{2}\right)$ & Then $(y)$ \\
\hline 1 & $\mathrm{Vl}$ & $\mathrm{In}$ & Definitely not & 14 & $\mathrm{Av}$ & $\mathrm{Qi}$ & Rather yes \\
\hline 2 & $\mathrm{Vl}$ & $\mathrm{Ai}$ & Definitely not & 15 & $\mathrm{Av}$ & $\mathrm{Vi}$ & Rather yes \\
\hline 3 & $\mathrm{Vl}$ & $\mathrm{Av}$ & Rather not & 16 & $\mathrm{Qh}$ & $\mathrm{In}$ & Rather not \\
\hline 4 & $\mathrm{Vl}$ & $\mathrm{Qi}$ & Rather not & 17 & $\mathrm{Qh}$ & $\mathrm{Ai}$ & Rather not \\
\hline 5 & $\mathrm{Vl}$ & $\mathrm{Vi}$ & Rather not & 18 & $\mathrm{Qh}$ & $\mathrm{Av}$ & Rather yes \\
\hline 6 & $\mathrm{Ql}$ & $\mathrm{In}$ & Definitely not & 19 & $\mathrm{Qh}$ & $\mathrm{Qi}$ & Rather yes \\
\hline 7 & $\mathrm{Ql}$ & $\mathrm{Ai}$ & Rather not & 20 & $\mathrm{Qh}$ & $\mathrm{Vi}$ & Definitely yes \\
\hline 8 & $\mathrm{Ql}$ & $\mathrm{Av}$ & Rather not & 21 & $\mathrm{Vh}$ & $\mathrm{In}$ & Rather not \\
\hline 9 & $\mathrm{Ql}$ & $\mathrm{Qi}$ & Rather not & 22 & $\mathrm{Vh}$ & $\mathrm{Ai}$ & Rather yes \\
\hline 10 & $\mathrm{Ql}$ & $\mathrm{Vi}$ & Rather yes & 23 & $\mathrm{Vh}$ & $\mathrm{Av}$ & Rather yes \\
\hline 11 & $\mathrm{Av}$ & $\mathrm{In}$ & Rather not & 24 & $\mathrm{Vh}$ & $\mathrm{Qi}$ & Definitely yes \\
\hline 12 & $\mathrm{Av}$ & $\mathrm{Ai}$ & Rather not & 25 & $\mathrm{Vh}$ & $\mathrm{Vi}$ & Definitely yes \\
\hline 13 & $\mathrm{Av}$ & $\mathrm{Av}$ & Rather yes & & & & \\
\hline
\end{tabular}

Table 5. Fuzzy interpretation of the linguistic output variable $y-I R F(U p h)$

\begin{tabular}{|l|c|c|c|}
\hline \multicolumn{2}{|l|}{$C_{k}$ fuzzy set of linguistic values for $I R F(U p h)$} & $\begin{array}{c}\text { Description } \\
\text { of the variable } y\end{array}$ & $\begin{array}{c}\text { Fuzzy evaluation } \\
\text { of membership } \mu(y)\end{array}$ \\
\hline Definitely yes & Dy & About 1 & $(0.5,1,1,1)$ \\
\hline Rather yes & Ry & About 0.67 & $(0.33,0.67,0.67,1)$ \\
\hline Rather not & Rn & About 0.33 & $(0,0.33,0.33,0.67)$ \\
\hline Definitely not & Dn & About 0 & $(0,0,0,0.5)$ \\
\hline
\end{tabular}

\subsubsection{Defuzzification}

In order to defuzzificate, the centre of gravity method is proposed. A crisp output value is derived from formula:

$$
y^{*}=\frac{\int y \cdot \mu_{r e s}(y) d y}{\int \mu_{r e s}(y) d y} .
$$

The crisp output value is used to specify the output conclusion, for which the membership value in $y=y^{*}$ will be the maximum value. 


\subsection{Module II}

In the life cycle of a building costs may be incurred and also benefits (profits). The following two cost analysis cases for which a model has been created should therefore be distinguished: $L C C A$, life cycle cost analysis, and WLCA, whole life cycle cost analysis.

The structure of the building life cycle cost estimation module considering the additive for risk is built on the theory of possibilities and therefore fuzzy sets are used. Fuzzy logic is integrated in the module with the most common net present worth method $(N P W)$, which is one of the dynamic methods of analysing the economic effectiveness of a construction investment based on discounted cash flows. The fuzzy NPW method is based on the decomposition of fuzzy set theorem, which allows to present any fuzzy set $A$ being a part of space $X$ in the form of the sum (treated in the set sense) of the fuzzy sets created by the $\alpha$-cross-sections which are also called as $\alpha$-level sets. The model assumptions are described in more details in author's publication (Plebankiewicz, Zima, \& Wieczorek, 2016, 2018).

The method includes the description of parameters only with use of convex and normal fuzzy sets (with a maximum membership level of 1.0) for which membership functions are continuous intervals. This requirement results mainly from the use of theorem of the decomposition of fuzzy sets, the Dong-Shah-Wong algorithm and one of the methods of defuzzification obtained values, called the centre of gravity.

If the parameter such as time, the discount rate, cost or income is not related to the risk influence, it is modelled as a certain value. In this case a fuzzy number of a singleton membership function with a membership level equals to 1.0 for the certain value (Figure 2a) should be adopted for the calculation. If instead, one of the parameters listed above is related to the impact of risk, it should take the form of an uncertain value shaped as a triangular fuzzy number or as a membership function, as in Figure $2 \mathrm{~b}$ (both in case of time and a discount rate parameters), or as in Figure 2c (for costs and incomes).

The calculation of the life cycle cost $\left(L C C_{i}\right)$ or the whole life cost $\left(W L C C_{i}\right)$ of the $i$-th building object variant is carried out on the basis of scheme presented in Figure 3, taking into account formulas (3) to (9).

The markings used in scheme in Figure 3 mean successively: ${ }^{\star}$ the necessity to perform calculations in the case of the identification of incomes; ${ }^{* \star}$ the necessity to perform calculations when the life cycles (periods of use) for alternative solutions of a building object are different; ${ }^{* *}$ the necessity to perform calculations when it is necessary to estimate the value of the risk addition.

a)

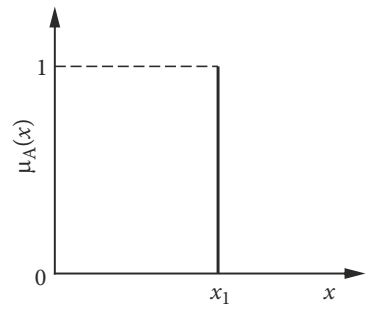

b)

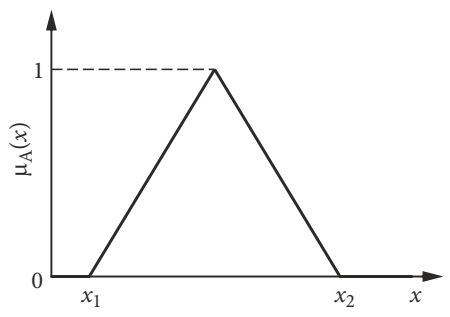

c)

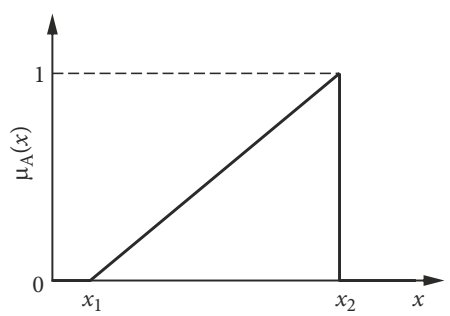

Figure 2. Forms of fuzzy numbers used in the module for estimating whole life cost of a building object 


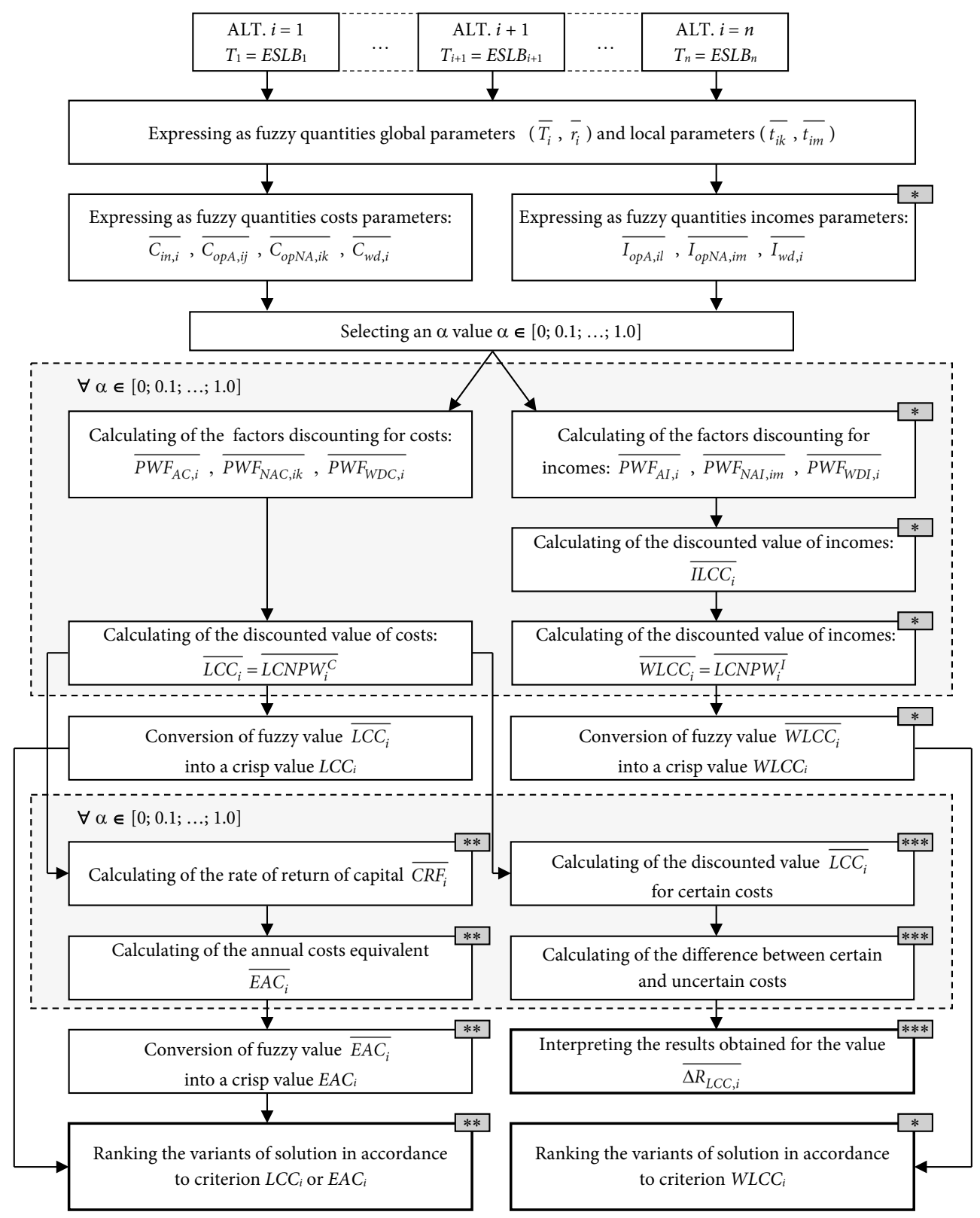

Figure 3. The calculation of the life cycle cost $\left(L C C_{i}\right)$ or the whole life cost $\left(W L C C_{i}\right)$ of the $i$-th building object variant 
The values of the present worth factors $(P W F)$ and life cycle cost $\left(L C C_{i}\right)$ or the whole life cost $\left(W L C C_{i}\right)$ can be calculated according to the following formulas:

- for annual operating costs and profits:

$$
\overline{P W F_{A C, i}}=\overline{P W F_{A I, i}}=\frac{1}{\overline{r_{i}}} \cdot\left(1-\left(1+\overline{r_{i}}\right)^{-\overline{T_{i}}}\right) ;
$$

- for periodic operating costs (after $k$-th time $t_{i k}$ ):

$$
\overline{P W F_{N A C, i k}}=\frac{1-\left(1+\overline{r_{i}}\right)^{-\overline{t_{i k}}}}{\left(1+\overline{r_{i}}\right)^{\overline{t_{i k}}}-1} ;
$$

- for periodic operating profits (after $m$-th time $t_{i m}$ ):

$$
\overline{P W F_{N A I, i m}}=\frac{1-\left(1+\overline{r_{i}}\right)^{-\overline{t_{i m}}}}{\left(1+\overline{r_{i}}\right)^{\overline{t_{i m}}}-1} ;
$$

- for withdrawal costs and profits related to the demolition phase after completion of estimated service life of the building in years $\left(E S L B_{i}\right)$ :

$$
\overline{P W F_{W D C, i}}=\overline{P W F_{W D I, i}}=\left(1+\overline{r_{i}}\right)^{-\overline{T_{i}}}
$$

- for the fuzzy value of life cycle costs $L C C_{i}=L C N P W_{i}^{C}$ :

$$
\begin{aligned}
& \overline{L C N P W_{i}^{C}}=\overline{C_{i n, i}}+\overline{P W F_{A C, i}} \cdot \sum_{j=1}^{n_{A C, i}} \overline{C_{o p A, i j}}+\sum_{k=1}^{n_{N A C, i}} \overline{C_{o p N A, i k}} \cdot \overline{P W F_{N A C, i k}}+ \\
& \overline{P W F_{W D C, i}} \cdot \overline{C_{w d, i}} ;
\end{aligned}
$$

- for the fuzzy value of life cycle incomes $I L C C_{i}$ :

$$
\overline{I L C C_{i}}=\overline{P W F_{A I, i}} \cdot \sum_{l=1}^{n_{A I, i}} \overline{I_{o p A, i l}}+\sum_{m=1}^{n_{N A I, i}} \overline{I_{o p N A, i m}} \cdot \overline{P W F_{N A I, i m}}+\overline{P W F_{W D I, i}} \cdot \overline{I_{w d, i}} ;
$$

- for the fuzzy value of whole life cost $W L C C_{i}=L C N P W_{i}^{I}$ :

$$
\overline{L C N P W_{i}^{I}}=\overline{I L C C_{i}}-\overline{L C N P W_{i}^{C}} .
$$

\section{Example calculation}

The model of estimating the total life cycle cost of a building, taking into account the risk addition, will be presented on the example of an office building. For the sake of simplicity, the assumption is that the investor will be the user of the facility, so only costs incurred in the life cycle are taken into account, excluding the potential gains.

Preliminary estimates indicate that the initial costs associated with planning, preparation and construction of the facility, assuming the investor's requirements for location, technology, conditions of use, etc., will be 6,200,000 PLN. The investor assumes the property's useful life for 40 years. For the assumed assumptions, the operating costs incurred in subsequent years of use were also estimated. 
These assumptions were adopted as a baseline scenario. The investor, however, wants to consider the risk involved in the incurred costs and to learn about their influence on the final cost.

The first step is to identify the risk factors and assess their impact on life cycle cost. The factors under consideration include, among others:

1) Wrongly estimated ground conditions;

2) The use of finishing materials with worse parameters than the ones planned.

For these two exemplary factors, calculations will be made according to module I of the model.

\subsection{Wrongly estimated ground conditions}

The investor has detailed geological and engineering documentation, as well as information on the course of existing networks and the utilities; therefore, it should be recognized that he/she has a good recognition of ground conditions. The probability of the occurrence of an undesirable event $P R(U p h)$, which is "Wrongly Recognized Ground Condition", can be described as "quite low". According to table 2: $P R(U p h)=0.30$.

Wrongly estimated ground conditions belong to one of the most frequent reasons for the changes in the planned amount of earthworks. Ground conditions that have been badly estimated may result in the need for land replacement, land drainage or applying a nonplanned technology, which often entails significant cost increases. The effects of mistakenly recognized ground conditions are particularly acute in the case of basement buildings. The analysed case deals with a building without a basement which, in consequence, allows to evaluate the effect of the occurrence of an undesirable event $E F F(U p h)$ as at least "quite important". According to Table 3: $E F F(U p h)=4.43$ (the impact determined as an arithmetic mean from the opinion of the 21 experts evaluating the effect of this risk factor in the context of its impact on costs - own survey).

The score, or function value $\operatorname{IRF}(U p h)=0.481$ (using the Mamdani's min and max implication and aggregation rules, and defuzzificating with the use of the centre of gravity method). The final result is formulated in the conclusion "Rather not", which in turn allows the investor to decide not to take into account the risk factor "Wrongly estimated ground conditions" in the calculations.

\subsection{The use of finishing materials with worse parameters than the ones designed}

The expenditure related to the implementation of the object is a significant financial burden for the investor. In the budget, the investor first draws attention to the costs associated with the construction of the building, without attaching much importance to the estimation of the cost of finishing works. The investor is aware that due to the use of the building and general conditions, the calculation of the cost of finishing works may be less precise. The implementation of finishing works at the end of the investment cycle, a limited budget and a large selection of finishing materials may result in the investor choosing to use cheaper and less expensive finishing materials than originally planned. The occurrence of the undesirable event $P R(U p h)$ which is "Use of finishing materials with worse parameters than the ones designed" can be described as "quite high". In accordance with Table 2: $P R(U p h)=0.70$. 
The costs of finishing works may amount to several dozen presents of the cost of the entire building. The use of materials with poorer performance than the ones designed may result in poor durability of the finishing materials, which, in turn, results in more frequent repairs and replacement. The evaluation of the effect of an adverse event $E F F(U p h)$ was defined as at least "quite important". Table 3 shows $E F F(U p h)=4.25$ (the impact determined as an arithmetic mean from the opinion of the 21 experts evaluating the effect of this risk factor in the context of its impact on costs - own survey).

The result, i.e. the value of the function $\operatorname{IRF}(U p h)=0.678$ (using Mamdani's min and max aggregation and aggregation rules and defuzzificating by centre of gravity). The final result is interpreter as the conclusion: "Rather yes", which in turn allows the investor to decide to take into account the risk factor "Wrongly estimated ground conditions" in the calculations.

The costs for the analysed building are specified for three variants. The reason for this is to take into account the impact on life cycle cost identified and assessed risk factor: "The use of finishing materials with worse parameters than the ones designed". Two types of reaction to the risk are proposed: "Risk allocation in initial investment costs" - more expensive replacement solutions at the stage of object implementation and "Transfer of risk to the operation phase" - more expensive replacement solutions at the repair stage.

The authors assume that it is very likely that market changes will occur in the future (that is during the operation of the object), as a result of which the risk of changing the discount rate is also included in the life cycle cost analysis, modelling it in the form of a range of achievable values. Detailed data is provided in Table 6. In the example, the withdrawal costs are not analysed because no demolition and/or resale are planned. No revenue is considered either. Thus life cycle cost are compared, not the whole life costs.

Table 7 lists the values of input parameters modelled by the triangular membership functions for the baseline scenario 0 and scenarios 1 and 2 in the selected $\alpha$ cross section of $\alpha=$ 0.5 .

Table 8 shows the output values calculated for all scenarios in the selected $\alpha$ cross section of $\alpha=0.5$.

Figures 3 and 4 represent the output membership functions for the cost comparison criteria and the cost additive for risk $\overline{\Delta R_{L C C, i}}$ respectively, for the analysed variants of the implementation of a construction object.

The Figure 4 shows, that the best solution for the planned investment is the implementation of baseline scenario 0 . That scenario generates the lowest value of the life cycle cost $(7,584,000$ PLN). However, in that scenario only the addition relating to financial risk was accounted for.

In the case of scenarios 1 and 2 the addition for both types of risk (financial and technological) are included. The best solution in this situation for the construction investment would be the implementation of scenario 2 - this assumes the transfer of technological risk to the maintenance stage and bearing higher costs for the general renovation of the building object after the thirtieth year of its use. Another reason for this solution is the fact that the difference between acute output values of additions for risk in scenarios 0 and 2 of the building life cycle is merely 22,800 PLN. 
Table 6. Data for the life cycle cost analysis

\begin{tabular}{|c|c|c|c|c|}
\hline \multicolumn{2}{|c|}{ Parameters } & Baseline scenario $i=0$ & Scenario $i=1$ & Scenario $i=2$ \\
\hline \multicolumn{2}{|c|}{$\begin{array}{l}\text { The type } \\
\text { of reaction } \\
\text { to risk }\end{array}$} & $\begin{array}{l}\text { Lack of reaction to risk } \\
\text { (allowing a solution } \\
\text { from the original design } \\
\text { concept) }\end{array}$ & $\begin{array}{l}\text { Allocation of risk } \\
\text { in initial costs (a more } \\
\text { expensive exchangeable } \\
\text { solution applied at the } \\
\text { stage of object }\end{array}$ & $\begin{array}{l}\text { Transfer of risk to the } \\
\text { maintenance stage (a more } \\
\text { expensive exchangeable } \\
\text { solution applied at the stage } \\
\text { of general renovation) }\end{array}$ \\
\hline \multicolumn{2}{|c|}{ Life cycle $T_{i}$} & 40 years & 40 years & 40 years \\
\hline \multicolumn{2}{|c|}{ Discount rate $r_{i}$} & $\begin{array}{l}\text { from } 6 \text { to } 10 \% \\
\text { (triangle membership } \\
\text { function, Figure } 2 . b \text { ) }\end{array}$ & $\begin{array}{l}\text { from } 6 \text { to } 10 \% \\
\text { (triangle membership } \\
\text { function, Figure } 2 . b \text { ) }\end{array}$ & $\begin{array}{l}\text { from } 6 \text { to } 10 \% \\
\text { triangle membership } \\
\text { function, Figure 2.b) }\end{array}$ \\
\hline \multicolumn{2}{|c|}{ Initial costs $C_{i n, i}$} & $6,200,000$ PLN & $\begin{array}{l}\text { max. 6,400,000 PLN } \\
\text { (triangle membership } \\
\text { function, Figure 2.c) }\end{array}$ & $6,200,000$ PLN \\
\hline \multicolumn{2}{|c|}{$\begin{array}{l}\text { Annual operating } \\
\text { costs } C_{o p A, i j}\end{array}$} & 98,000 PLN & 98,000 PLN & 98,000 PLN \\
\hline \multirow{3}{*}{ 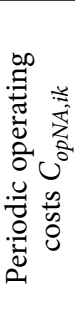 } & $\begin{array}{c}\text { after } \\
10^{\text {th }} \text { year: }\end{array}$ & 240,000 PLN & 240,000 PLN & $\begin{array}{l}\text { max. } 288,000 \text { PLN } \\
\text { (triangle membership } \\
\text { function, Figure } 2 . c \text { ) }\end{array}$ \\
\hline & $\begin{array}{l}\text { after } 20^{\text {th }} \\
\text { year: }\end{array}$ & 240,000 PLN & 240,000 PLN & $\begin{array}{l}\text { max. } 288,000 \text { PLN } \\
\text { (triangle membership } \\
\text { function, Figure 2.c) }\end{array}$ \\
\hline & $\begin{array}{l}\text { after } 30^{\text {th }} \\
\text { year: }\end{array}$ & 240,000 PLN & 240,000 PLN & $\begin{array}{l}\text { max. } 288,000 \text { PLN } \\
\text { (triangle membership } \\
\text { function, Figure 2.c) }\end{array}$ \\
\hline
\end{tabular}

Table 7. Values of selected input parameters in section $\alpha=0.5$

\begin{tabular}{|l|c|c|c|c|c|c|c|}
\hline \multicolumn{2}{|c|}{ Parameters } & \multicolumn{2}{|c|}{ Baseline scenario $i=0$} & \multicolumn{2}{c|}{ Scenario $i=1$} & \multicolumn{2}{c|}{ Scenario $i=2$} \\
\cline { 3 - 8 } & $\begin{array}{c}0.5 \\
\text { (left edge) }\end{array}$ & $\begin{array}{c}0.5 \\
\text { (right edge) }\end{array}$ & $\begin{array}{c}0.5 \\
\text { (left edge) }\end{array}$ & $\begin{array}{c}0.5 \\
\text { (right edge) }\end{array}$ & $\begin{array}{c}0.5 \\
\text { (left edge) }\end{array}$ & $\begin{array}{c}0.5 \\
\text { (right edge) }\end{array}$ \\
\hline $\begin{array}{l}\text { Discount } \\
\text { rate } r_{i}\end{array}$ & {$[\%]$} & 7 & 9 & 7 & 9 & 7 & 9 \\
\hline $\begin{array}{l}\text { Initial } \\
\text { costs } C_{i n, i}\end{array}$ & {$[\mathrm{PLN}]$} & $6,200,000$ & $6,200,000$ & $6,300,000$ & $6,400,000$ & $6,200,000$ & $6,200,000$ \\
\hline $\begin{array}{l}\text { Periodic } \\
\text { operating } \\
\text { costs } C_{\text {onNA,i10, }} \\
C_{\text {onNA,i20, }} \\
C_{\text {opNA,i30 }}\end{array}$ & {$[\mathrm{PLN}]$} & 240,000 & 240,000 & 240,000 & 240,000 & 264,000 & 288,000 \\
\hline
\end{tabular}

Table 8. Values calculated in the section $\alpha=0.5$

\begin{tabular}{|c|c|c|c|c|c|c|}
\hline \multirow{2}{*}{$\begin{array}{c}\text { Values } \\
\text { calculated }\end{array}$} & \multicolumn{2}{|c|}{ Baseline scenario $i=0$} & \multicolumn{2}{c|}{ Scenario $i=1$} & \multicolumn{2}{c|}{ Scenario $i=2$} \\
\cline { 2 - 7 } & $\begin{array}{c}0.5 \\
\text { (left edge) }\end{array}$ & $\begin{array}{c}0.5 \\
\text { (right edge) }\end{array}$ & $\begin{array}{c}0.5 \\
\text { (left edge) }\end{array}$ & $\begin{array}{c}0.5 \\
\text { (right edge) }\end{array}$ & $\begin{array}{c}0.5 \\
\text { (left edge) }\end{array}$ & $\begin{array}{c}0.5 \\
\text { (right edge) }\end{array}$ \\
\hline$L C C_{i}[$ PLN] & $7,416,512$ & $7,722,060$ & $7,616,512$ & $7,822,060$ & $7,448,971$ & $7,743,615$ \\
\hline$\Delta R_{L C C, i}[$ PLN] & $\begin{array}{c}\text { not } \\
\text { applicable }\end{array}$ & $\begin{array}{c}\text { not } \\
\text { applicable }\end{array}$ & $-105,548$ & 405,548 & $-273,089$ & 327,103 \\
\hline
\end{tabular}




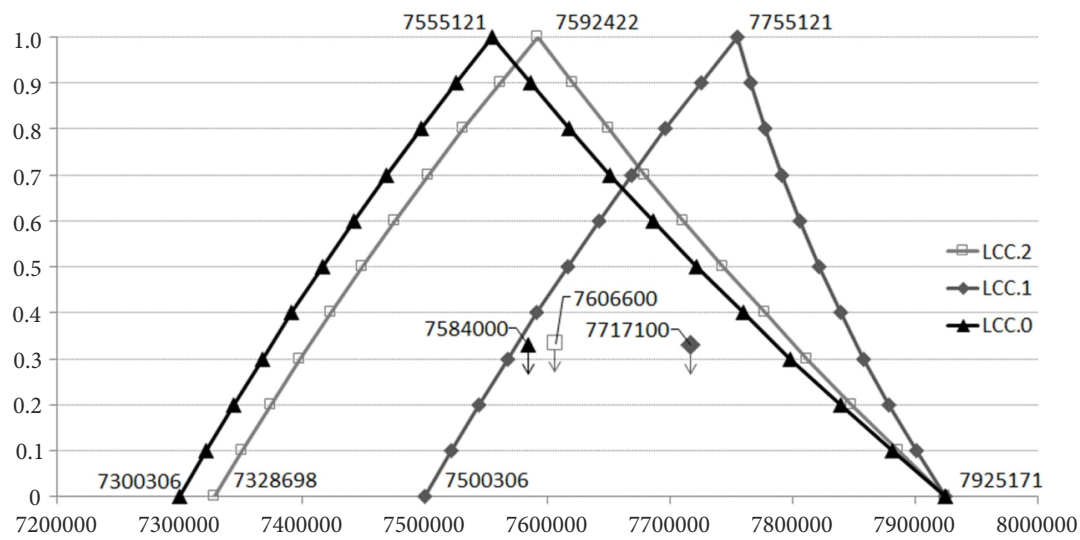

Figure 4. Output membership functions for the criterion $\overline{L C C_{i}}$

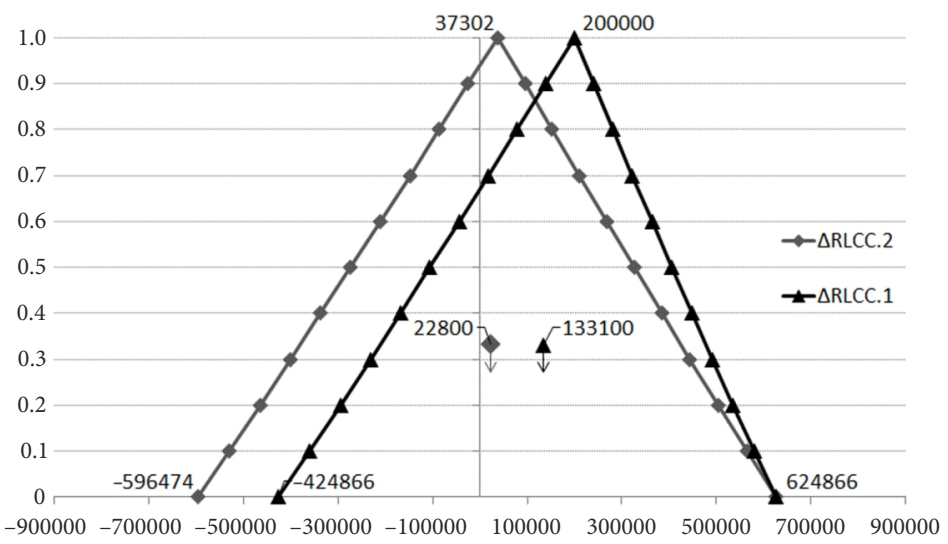

Figure 5. Output membership functions for the criterion $\overline{\Delta R_{L C C, i}}$

It is interesting, that the resulting fuzzy distributions for the addition of risk (Figure 5) indicate that during the life cycle of the building (with a reasonably large probability for scenario 2), there may occur such circumstances, which due to the existing risk, will not constitute a loss for the investor, but will generate a profit (when $\Delta R_{L C C, i}<0$ ).

\section{A model verification}

Because both modules of model (module I evaluating the impact of identified risk factors on the individual element of life cycle cost, and module II allowing to assess life cycle cost including the risk factors selected in module I) can work independently, the authors present the ways for their verification separately.

\subsection{Module I}

In order to defuzzificate, this operation aims to determine one crisp value $y^{*}$ which will adequately represent the output fuzzy set. 
In fuzzy reasoning (according to Mamdani's approach) the final result can be formed in a number of ways. Commonly used defuzzification methods are: first of maxima method, middle of maxima method, last of maxima method, centre of gravity method, bisector area method, weighted average method, height method, centre of sums method and centre of largest area method. In the author's publication (Wieczorek, 2018) the possibilities of applying particular defuzzification methods in module I were described in detail.

Figures 6 and 7 illustrate two example planes of solutions that were obtained using the smallest of maxima method and centre of gravity method.

The main assumption of designing the rule base process was that with the increase of the probability and the effect of occurrence of a unwanted phenomenon, the impact of the identified risk factor on the size of the corresponding component of the life cycle cost of the building is to grow in a gentle (non-stop) manner. Therefore the centre of gravity method was finally proposed in module I evaluating the impact of identified risk factors on the individual element of life cycle cost as a right defuzzification method.

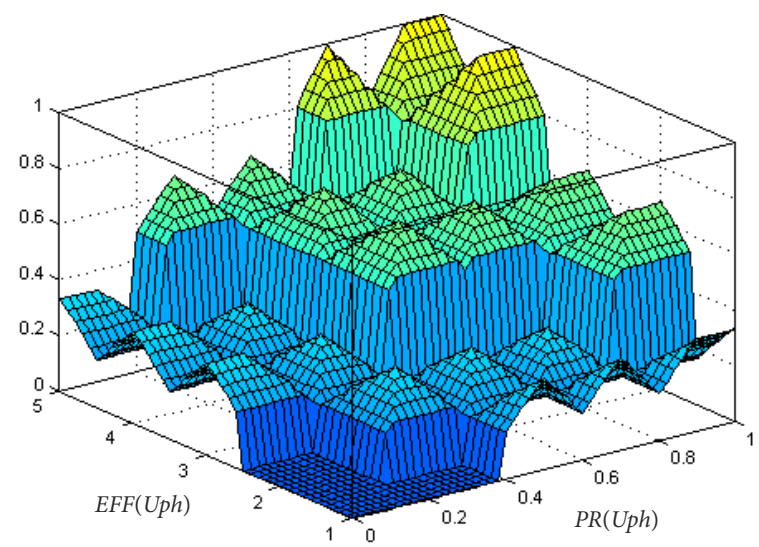

Figure 6. Surface solutions - smallest of maxima method

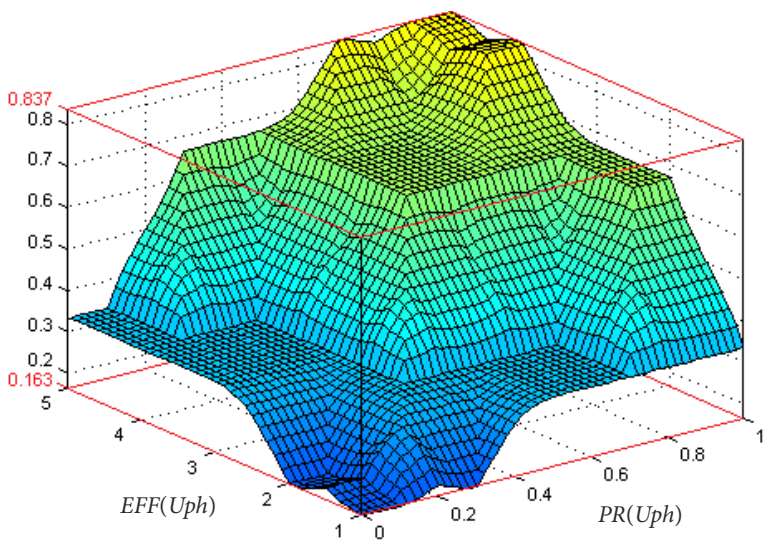

Figure 7. Surface solutions - centre of gravity method 


\subsection{Module II}

The ISO 15686-5:2008 standard (International Organization for Standardization, 2008) draws attention in "Annex D" to the need to make sensitivity study in each case of calculating the life cycle cost $L C C$ (or whole life cost WLC) of buildings.

Sensitivity study calculates how changes in particular assumptions (regarding to the costs, time or discount rate) would affect the values of $L C C$ (or WLC) of buildings. Annex D of ISO 15686-5:2008 standard suggests providing an LCC sensitivity analysis, e.g. at various discount rates and the impact of changes in investment or operating costs by $+10 \%$ and $-10 \%$.

The authors prepared the sensitivity analysis of the module II in accordance with the ISO 15686-5:2008 standard guidelines. For the baseline scenario 0, the impact of changing the discount rate from $-1 \%$ to $+1 \%$ on the $L C C$ result was checked. For the scenario 1 (allocation of risk in initial costs), the value of initial costs $\left(C_{i n, 1}=\max .6,400,000\right.$ PLN $)$ by $+10 \%$ and $-10 \%$ was changed. For the scenario 2 (transfer of risk to the maintenance stage), the value of periodic operating costs after $10^{\text {th }}, 20^{\text {th }}$ and $30^{\text {th }}$ year $\left(C_{o p N A, 210}=C_{o p N A, 220}=\right.$ $C_{o p N A, 230}=\max .288,000$ PLN) by $+10 \%$ and $-10 \%$ was also changed.

The results of sensitivity study are presented in Table 9.

In the case of scenario 0 in which the discount rate was changed from 5 to $9 \%$ and from 7 to $11 \%$, the $L C C$ values $7,758,900$ PLN and 7,439,300 PLN respectively were obtained. These were respectively $2.31 \%$ higher and $1.91 \%$ lower LCC values than LCC at the basic discount rate from 6 to $10 \%(7,584,000$ PLN) for the calculation example. For the scenario 1 in which the investment costs was changed from max. 5,760,000 PLN to max. 7,040,000 PLN, the $L C C$ values 7,083,800 PLN and 8,350,400 PLN respectively were obtained. These were respectively $8.21 \%$ lower and $8.21 \%$ higher $L C C$ values than $L C C$ at the basic investment costs $(7,717,100$ PLN). For the scenario 2 in which the periodic operating costs was changed

Table 9. Results of sensitivity study for the $L C C_{i}$ values in the section $\alpha=0.5$

\begin{tabular}{|c|c|c|c|c|c|c|}
\hline \multirow{2}{*}{ Assumptions changed } & \multicolumn{2}{|c|}{ Baseline scenario $i=0$} & \multicolumn{2}{|c|}{ Scenario $i=1$} & \multicolumn{2}{|c|}{ Scenario $i=2$} \\
\hline & $\begin{array}{c}0.5 \\
\text { (left edge) }\end{array}$ & $\begin{array}{c}0.5 \\
\text { (right edge) }\end{array}$ & $\begin{array}{c}0.5 \\
\text { (left edge) }\end{array}$ & $\begin{array}{c}0.5 \\
\text { (right edge) }\end{array}$ & $\begin{array}{c}0.5 \\
\text { (left edge) }\end{array}$ & $\begin{array}{c}0.5 \\
\text { (right edge) }\end{array}$ \\
\hline $\begin{array}{l}\text { Discount rate } r_{i} \\
\text { from } 6 \text { to } 10 \% \\
\text { from } 5 \text { to } 9 \% \\
\text { from } 7 \text { to } 11 \%\end{array}$ & $\begin{array}{c}\text { PLN } \\
7,416,512 \\
7,300,306 \\
7,555,121\end{array}$ & $\begin{array}{c}\text { PLN } \\
7,722,060 \\
7,555,121 \\
7,925,171\end{array}$ & $\begin{array}{c}\text { not } \\
\text { applicable }\end{array}$ & $\begin{array}{c}\text { not } \\
\text { applicable }\end{array}$ & $\begin{array}{c}\text { not } \\
\text { applicable }\end{array}$ & $\begin{array}{c}\text { not } \\
\text { applicable }\end{array}$ \\
\hline $\begin{array}{l}\text { Initial costs } C_{i n, i} \\
\text { max. } 6,400,000 \text { PLN } \\
\text { max. } 5,760,000 \text { PLN } \\
\text { max. } 7,040,000 \text { PLN }\end{array}$ & $\begin{array}{c}\text { not } \\
\text { applicable }\end{array}$ & $\begin{array}{c}\text { not } \\
\text { applicable }\end{array}$ & $\begin{array}{c}\text { PLN } \\
7,616,512 \\
6,976,512 \\
8,256,512\end{array}$ & $\begin{array}{c}\text { PLN } \\
7,822,060 \\
7,192,060 \\
8,452,060\end{array}$ & $\begin{array}{c}\text { not } \\
\text { applicable }\end{array}$ & $\begin{array}{c}\text { not } \\
\text { applicable }\end{array}$ \\
\hline $\begin{array}{l}\text { Periodic operating costs } \\
C_{\text {onNA,i10 }}, C_{\text {onNA,i20, }} \\
C_{o p N A, i 30} \\
\text { max. } 288,000 \text { PLN } \\
\text { max. } 259,200 \text { PLN } \\
\text { max. } 316,800 \text { PLN }\end{array}$ & $\begin{array}{c}\text { not } \\
\text { applicable }\end{array}$ & $\begin{array}{c}\text { not } \\
\text { applicable }\end{array}$ & $\begin{array}{c}\text { not } \\
\text { applicable }\end{array}$ & $\begin{array}{c}\text { not } \\
\text { applicable }\end{array}$ & $\begin{array}{l}7,448,971 \\
7,429,496 \\
7,468,446\end{array}$ & $\begin{array}{l}7,743,615 \\
7,719,904 \\
7,767,326\end{array}$ \\
\hline
\end{tabular}


from max. 259,200 PLN to max. 316,800 PLN, the $L C C$ values 7,585,200 PLN and 7,628,000 PLN respectively were obtained. These were respectively $0.28 \%$ lower and $0.28 \%$ higher $L C C$ values than $L C C$ at the basic periodic operating costs (7,606,600 PLN).

Sensitivity analyses for the addition of risk $\left(\Delta R_{L C C}\right)$ was not carried out in this study.

\section{Conclusions}

In the paper the author's proposal of a model for estimating the life cycle cost (and the whole life cost) of a building that takes into account the risk an original is presented.

The proposed model consists of two basic parts: module I evaluating the influence of identified risk factors on the individual element of life cycle cost, and module II allowing to assess life cycle cost including the risk factors selected in module I. The authors did not limit themselves to creating an outline of the model, a computational algorithm, or a way to combine the two modules into a whole. The authors proposed a definition of addition for the risk as a difference expressed in monetary units between the sum of a building life-cycle cost which involves the impact of risk, and the sum of the building life cycle cost which excludes risk (Plebankiewicz, Zima, \& Wieczorek, 2017).

The authors did their own research to determine the effect of the occurrence of risk factors identified in each phase of the life cycle of the building. These studies were based on literature studies and questionnaires. On the basis of literature sources, risk factors were identified and categorised according to the life cycle of the building, their character (category) and the risk-bearing participants of the construction process. Then experts selected by the authors assessed (in a scale from 1 to 5 , where 1 - insignificant impact, 5 - very significant impact) the influence of the particular risk factor on the size of the corresponding life cycle component. The authors believe that the risk research is an important contribution to the model.

The authors decided to divide the model into two modules in order to emphasize the importance of risk in cost analysis. The original elements of the model are the previously mentioned selection and division of risk depending on the LCC analysis stage, and also the quantifying method of the risk factor that was assessed with module I of the model (resulting from the meaning of the definition of addition for the risk). It seems that an interesting approach is also the creation of a baseline scenario, to which the remaining scenarios to be analysed are referred (built on the basis of the type of response to risk).

Regarding the choice of methodology in the context of the construction of module II, the authors based their calculation algorithm on the theory of possibilities and the fuzzy logic. This is primarily due to the fact that the risk assessor may not have a sufficient amount of data to do a statistical analysis which would result in a probabilistic probability distribution. This ultimately determines, in a subjective way, the value of the parameters adopted for the efficiency account. It should also be pointed out that there are situations in which the nature of the uncertainty of the parameters of an economic effect cannot be related to the theory of probability because it is related to a unique, one-time occurrence.

As it results from the verification process of module II, changing the value of the discount rate from $-1 \%$ to $+1 \%$ has a very small impact on the received $L C C$ values (change in the 
LCC values by $-1.91 \%$ and $+2.31 \%$ ). The same applies to changes in the value of periodic operating costs from $-10 \%$ to $+10 \%$ (change in the $L C C$ values by $\pm 0.28 \%$ ). The change in investment costs from $-10 \%$ to $+10 \%$ caused a change in the $L C C$ values by $\pm 8.21 \%$. This is due to the fact that the investor incurs the investment costs at the present time (during the implementation phase), and not later in the operation phase of the building life cycle.

\section{References}

Ammar, M., Zayed, T., \& Mosehli, O. (2012). Fuzzy-based life-cycle cost model for decision making under subjectivity. Journal of Construction Engineering and Management, 139(5), 556-563. https://doi.org/10.1061/(ASCE)CO.1943-7862.0000576

Aye, L., Bamford, N., Charters, B., \& Robinson, J. (2000). Environmentally sustainable development: a life-cycle costing approach for a commercial office building in Melbourne, Australia. Construction Management \& Economics, 18(8), 927-934. https://doi.org/10.1080/014461900446885

Bromilow, F. J., \& Pawsey, M. R. (1987). Life cycle cost of university buildings. Construction Management and Economics, 5(4), 3-22. https://doi.org/10.1080/01446193.1987.10462089

Flanagan, R., \& Norman, G. (1983). Life cycle costing for construction. London, UK: Quantity Surveyors Division of the Royal Institution of Chartered Surveyors.

Flanagan, R., Kendell, A., Norman, G., \& Robinson, G. D. (1987). Life cycle costing and risk management. Construction Management and Economics, 5(4), 53-71. https://doi.org/10.1080/01446193.1987.10462093

Frangopol, D. M., Lin, K. Y., \& Estes, A. C. (1997). Life-cycle cost design of deteriorating structures. Journal of Structural Engineering, 123(10), 1390-1401.

https://doi.org/10.1061/(ASCE)0733-9445(1997)123:10(1390)

Fuller, S. K., \& Boyles, A. S. (2000). Life-cycle costing workshop for energy conservation in buildings: student manual. Gaithersburg, USA: National Institute of Standards and Technology.

Gluch, P., \& Baumann, H. (2004). The life cycle costing (LCC) approach: a conceptual discussion of its usefulness for environmental decision-making. Building and Environment, 39, 571-580. https://doi.org/10.1016/j.buildenv.2003.10.008

Goh, K. C., \& Yang, J. (2010, May). Incorporating sustainability measures in life-cycle financial decision making for highway construction. In Proceedings of New Zealand Sustainable Building ConferenceSB10. Retrieved from https://www.irbnet.de/daten/iconda/CIB18088.pdf

Hasan, A., Vuolle, M., \& Siren, K. (2008). Minimisation of life cycle cost of a detached house using combined simulation and optimisation. Building and Environment, 43(12), 2022-2034. https://doi.org/10.1016/j.buildenv.2007.12.003

Ilg, P., Scope, Ch., Muench, S., \& Guenther, E. (2017). Uncertainty in life cycle costing for long-range infrastructure. Part I: leveling the playing field to address uncertainties. International Journal of Life Cycle Assessment, 22(2), 277-292. https://doi.org/10.1007/s11367-016-1154-1

International Organization for Standardization. (2008). Buildings and constructed assets. Service life planning. Part 5: Life cycle costing. (ISO 15686-5:2008). Geneva, Switzerland: International Organization for Standardization.

Kale, N. N., Joshi, D., \& Menon, R. (2016). Life cycle cost analysis of commercial buildings with energy efficient approach. Perspectives in Science, 8, 452-454. https://doi.org/10.1016/j.pisc.2016.04.102

Kartam, N. A., \& Kartam, S. A. (2001). Risk and its management in the Kuwaiti construction industry: a contractors' perspective. International Journal of Project Management, 19(6), 325-335.

https://doi.org/10.1016/S0263-7863(00)00014-4 
Koo, Ch., Hong, T., \& Park, J. (2018). Development of the life-cycle economic and environmental assessment model for establishing the optimal implementation strategy of the rooftop photovoltaic system. Technological and Economic Development of Economy, 24(1), 27-47. https://doi.org/10.3846/20294913.2015.1074127

Leśniak, A., \& Zima, K. (2018). Cost calculation of construction projects including sustainability factors using the Case Based Reasoning (CBR) method. Sustainability, 10, 1608. https://doi.org/10.3390/su10051608

Mamdani, E. H. (1974). Application of fuzzy algorithms for control of simple dynamic plant. Electrical Engineers, 121(12), 1585-1588. https://doi.org/10.1049/piee.1974.0328

Mamdani, E. H. (1977). Application of fuzzy logic to approximate reasoning using linguistic synthesis. IEEE Transactions on Computers, 100(12), 1182-1191. https://doi.org/10.1109/TC.1977.1674779

Marszal, A. J., \& Heiselberg, P. (2011). Life cycle cost analysis of a multi-storey residential net zero energy building in Denmark. Energy, 36(9), 5600-5609. https://doi.org/10.1016/j.energy.2011.07.010

Menassa, C. C. (2011). Evaluating sustainable retrofits in existing buildings under uncertainty. Energy and Buildings, 43(12), 3576-3583. https://doi.org/10.1016/j.enbuild.2011.09.030

Oduyemi, O., Okoroh, M., \& Fajana, O. S. (2016). Risk assessment methods for life cycle costing in buildings. Sustainable Buildings, 1, 3. https://doi.org/10.1051/sbuild/2016005

Plebankiewicz, E. (2014). Kierunki działań zmierzających do obniżenia kosztów w cyklu życia budynków miejskich. In A. Halicka (Ed.), Budownictwo na obszarach zurbanizowanych: Nauka, praktyka, perspektywy (pp. 271-282). Lublin: Wydawnictwo Politechniki Lubelskiej.

Plebankiewicz, E., Zima, K., \& Wieczorek, D. (2015, June). Review of methods of determining the life cycle cost of buildings. In M. Hajdu (Ed.), Proceedings of the CC 2015, Creative Construction Conference, Kraków, Poland (pp. 309-316). Amsterdam, Netherlands: Elsevier B.V.

Plebankiewicz, E., \& Wieczorek, D. (2016). Rozmyta ocena ryzyka w cyklu życia obiektów budowlanych. Materiały Budowlane, 6(526), 59-61. https://doi.org/10.15199/33.2016.06.25

Plebankiewicz, E., Zima, K., \& Wieczorek, D. (2016) Life cycle cost modelling of buildings with consideration of the risk. Archives of Civil Engineering, 62(2), 35-45. https://doi.org/10.1515/ace-2015-0071

Plebankiewicz, E., Zima, K., \& Wieczorek, D. (2017). Quantification of the risk addition in life cycle cost of a building object. Technical Transactions, 5, 149-166.

Plebankiewicz, E., Zima, K., \& Wieczorek, D. (2018). Life Cycle Equivalent Annual Cost (LCEAC) as a comparative indicator in the life cycle cost analysis of buildings with different lifetimes. In MATEC Web of Conferences, 196. Article ID 04079. Les Ulis Cedex, France: EDP Sciences. https://doi.org/10.1051/matecconf/201819604079

Robinson, J. (1986). Life cycle costing in buildings: a practical approach. Australian Institute of Building Papers, 1, 13-28.

Stone, P. A. (1967). Building design evaluation. Suffolk, UK: The Chaucer Press Ltd.

Shevchenko, G., Ustinovichius, L., \& Andruškevičius, A. (2008). Multi-attribute analysis of investments risk alternatives in construction. Technological and Economic Development of Economy, 14(3), 428443. https://doi.org/10.3846/1392-8619.2008.14.428-443

Sobanjo, J. O. (1999, May-June). Facility life-cycle cost analysis based on fuzzy set theory. In M. A. Lacasse \& D. J. Vanier (Eds.), Proceedings of the Eighth International Conference on Durability of Building Materials and Components (Vol. 3, pp. 1798-1809). Vancouver, Canada: NRC Research Press.

Sterner, E. (2002). Green procurement of buildings: estimation of environmental impact and life-cycle cost. Lulea: Lulea Tekniska Universitet.

Wieczorek, D. (2018). Fuzzy risk assessment in the life cycle of building object - selection of the right defuzzification method. In AIP Conference Proceedings, 1978(1), 240005. Melville, NY: AIP Publishing. https://doi.org/10.1063/1.5043866 
Wiguna, I. P. A., \& Scott, S. (2006). Relating risk to project performance in Indonesian building contracts. Construction Management and Economics, 24(11), 1125-1135.

https://doi.org/10.1080/01446190600799760

Yi, H., \& Wen-jie, H. (2009, December). Analysis of the life cycle cost of the power plants based on analytic hierarchy process method. In 2009 International Conference on Information Management, Innovation Management and Industrial Engineering (Vol. 4, pp. 639-642). USA, Canada: IEEE. https://doi.org/10.1109/ICIII.2009.613

Yuting, S., \& Carmichael, D. G. (2018). Uncertainties related to financial variables within infrastructure life cycle costing: a literature review. Structure and Infrastructure Engineering, 14(9), 1233-1243. https://doi.org/10.1080/15732479.2017.1418008

Zavadskas, E. K., Antuchevičienè, J., \& Kapliński, O. (2015a). Multi-criteria decision making in civil engineering: Part I - a state-of-the-art survey. Engineering Structures and Technologies, 7(3), 103113. https://doi.org/10.3846/2029882X.2015.1143204

Zavadskas, E. K., Antuchevičienè, J., \& Kapliński, O. (2015b). Multi-criteria decision making in civil engineering. Part II - applications. Engineering Structures and Technologies, 7(4), 151-167. https://doi.org/10.3846/2029882X.2016.1139664

Zhi, H. (1995). Risk management for overseas construction projects. International Journal of Project Management, 13(4), 231-237. https://doi.org/10.1016/0263-7863(95)00015-I 